\title{
Seasonal study on ectoenzyme activities, carbohydrate concentrations, prokaryotic abundance and production in a solar saltern in Korea
}

\author{
J. S. Park, D. H. Choi, C. Y. Hwang, G. J. Park, B. C. Cho* \\ School of Earth and Environmental Sciences, Seoul National University, Seoul 151-742, Republic of Korea
}

\begin{abstract}
Solar salterns in temperate climates commercially produce salt in the summer. To determine whether prokaryotic growth-related variables vary seasonally along the salinity gradient, ectoenzyme activities, prokaryotic abundance (PA), prokaryotic heterotrophic production (PHP) and environmental variables were measured in a solar saltern in 1999 and 2001. In low-salinity (i.e. $<120 \%$ ) ponds, where marine bacteria are known to dominate the prokaryotic community, positive relationships of ectoenzyme activities with PA (aminopeptidase: $\mathrm{r}^{2}=0.51, \mathrm{p}<0.01, \mathrm{n}=16$; $\beta$-glucosidase: $\mathrm{r}^{2}=0.57, \mathrm{p}<0.01, \mathrm{n}=17$ ), temperature $\left(\beta\right.$-glucosidase: $\left.\mathrm{r}^{2}=0.56, \mathrm{p}<0.01, \mathrm{n}=17\right)$ and PHP (aminopeptidase: $\mathrm{r}^{2}=0.25, \mathrm{p}<0.05, \mathrm{n}=16$ ) were observed, as also reported for ordinary marine environments. However, in high-salinity (i.e. $\geq 120 \%$ ) ponds, the relationships became insignificant or weak, and a strongly negative relationship between aminopeptidase activity and salinity $\left(\mathrm{r}^{2}=0.71\right.$, $\mathrm{p}<0.01, \mathrm{n}=19$ ) was found. Thus, the high salinity seems to significantly reduce ectoenzyme activities. In high-salinity ponds (120 to $390 \%$ o) per-cell ectoenzyme activities decreased by as much as 2 to 3 orders of magnitude. Furthermore, substrate-addition and temperature-treatment experiments indicated that limiting factors for PHP vary seasonally in the saltern. PHP was limited by organic compounds (i.e. glucose and an amino acid mixture) in the spring at a salinity of $120 \%$ and by osmoregulatory substances (i.e. betaine) in the summer at salinities of 260 to $390 \%$, and temperature in the autumn at 29 to $213 \%$. Despite the dominant influence of high salinity on prokaryotic activities, relationships between prokaryotic parameters varied seasonally both in low-salinity and in high-salinity ponds. Thus, it seems that prokaryotic variables along the salinity gradient in the saltern are controlled by different factors over seasonal cycles.
\end{abstract}

KEY WORDS: Ectoenzyme activity - Mono- and polysaccharides - Prokaryotes · Abundance · Production $\cdot$ Solar saltern $\cdot$ Seasonal variation

\section{INTRODUCTION}

In multi-pond solar salterns, the salinity of each pond is kept within a narrow range. Thus, each pond can be considered to be in chemical equilibrium (Pedrós-Alió et al. 2000). Solar salterns in temperate climate zones begin commercial production of salt in early spring and end production in autumn. During the salt production period, the seasonal variations in weather conditions (temperature, wind speed, precipitation and light intensity) are considerable. Therefore, the response of the prokaryotic community could change according to those seasonal variations in environmental variables. Javor (1983) showed that tropical salterns had less chlorophyll a (chl a) and fewer nutrient variations than similar systems located in the temperate zone. Based on comparisons of the polar lipid and metabolic profiles of 2 solar salterns in Newark, California, USA, and Eilat, Israel, Litchfield et al. $(2000,2001)$ noted seasonal differences in the saltern microbial communities. However, seasonal studies on prokaryotic growth-related variables along a salinity gradient have not been made (Gasol et al. 2004).

Generally, changes in salt concentration and composition along a salinity gradient play critical roles in regulat- 
ing microbial communities and activities in the salterns (Rodríguez-Valera 1988). Turnover times of the prokaryotic community increased with increasing salinity in the saltern, and prokaryotic abundance (PA) generally reached its plateau at salinities around 200 to $250 \%$ o (GuixaBoixareu et al. 1996, Pedrós-Alió et al. 2000, Gasol et al. 2004). Characteristics of community composition and, consequently, prokaryotic utilization of organic matter also vary along a salt gradient (Pedrós-Alió et al. 2000, Casamayor et al. 2002, Joint et al. 2002). In ponds with salinities $<80 \%$, the community is similar to a coastal marine community. At the next salinity level (80 to $200 \%$ o), increased flux of photosynthetically produced organic matter would be provided to moderately halophilic bacteria. At higher salinities (i.e. 200 to $300 \%$ ), primary production might decrease, and some marine phytoplankton would die. Presumably, halophilic prokaryotes will experience a decreased flux of organic matter. Further, near-saturating salt concentrations in crystallizers will inhibit growth of both non-extreme halophilic bacteria and archaea (Rodríguez-Valera 1988).

Typical distribution patterns of prokaryotic growth observed along the salinity gradient could be due to substrate limitation in hypersaline ponds. However, limitation of prokaryotic heterotrophic production (PHP) by organic substrates decreased as salinity increased (Gasol et al. 2004). Some prokaryotes in high-salinity ponds might not be at their optimal salinity for growth in situ (Gasol et al. 2004). In fact, halophilic bacteria recently isolated from crystallizers showed their optimal growth at much lower salinity ranges (Choi \& Cho 2005, Choi et al. 2006). Thus, the effect of the availability of osmoregulatory substances such as glycine betaine on prokaryotic growth in solar salterns needs to be assessed. Betaine is a well-known osmoregulatory substance of moderately halophilic bacteria, and the intracellular concentration of betaine is on the order of 100 to $1000 \mathrm{mM}$ (Imhoff \& Rodríguez-Valera 1984). Thus, betaine might occur in hypersaline environments as a result of cell death (Welsh 2000). In addition, temperature is generally considered an important factor in regulating prokaryotic growth in marine environments (Shiah \& Ducklow 1994). However, the effect of temperature on prokaryotic growth has rarely been investigated in solar salterns. Further, studies on hydrolytic ectoenzyme activity indicating cleavage of organic matter for subsequent uptake have not been made in solar salterns, despite the fact that polymers are more common in seawater than monomers and utilization of polymers is a prerequisite to prokaryotic growth (Billen 1984).

The goals of this study were to determine whether prokaryote-related variables showed marked seasonal variations in a solar saltern located in a temperate zone and to understand which factor(s) controlled prokaryotic growth and utilization of organic matter. We measured ectoenzyme activities (i.e. aminopeptidase and $\beta$-glucosidase) and thymidine (TdR) incorporation rates, along with environmental variables including the concentration of mono- and polysaccharides in a solar saltern in Korea. In addition, the effects of various substrates and varying temperature on PHP were measured.

\section{MATERIALS AND METHODS}

Study area and sample collection. Samples were collected in October 1998, in June, August and October 1999 and in April, June, August and September 2001 from a multi-pond solar saltern at Seosin $\left(37^{\circ} 09^{\prime} 36^{\prime \prime} \mathrm{N}, 126^{\circ} 40^{\prime} 44^{\prime \prime} \mathrm{E}\right)$, on the west coast of Korea. Samples could not be collected from the closed crystallizer in October 1999. For detailed descriptions of the saltern, see Park et al. (2003). Surface samples were taken with a 11 polycarbonate bottle at the seawater inlet and with $50 \mathrm{ml}$ polypropylene tubes at the other salt ponds. Samples were taken carefully in order to exclude collecting organic matter scums and debris at the sides of the salt ponds. In each sample, carbohydrate concentrations, PA, PHP and ectoenzyme activities were determined as described below.

Prokaryotic abundance and prokaryotic heterotrophic production. Samples for measurements of PA were fixed with $0.2 \mu \mathrm{m}$ filtered, borate-buffered formaldehyde (final conc. of $2 \%$ ). Prokaryotes, stained with DAPI (4', 6-diamidino-2-phenylindole; final conc. of $1 \mu \mathrm{g} \mathrm{ml}^{-1}$ ) and collected on black $0.2 \mu \mathrm{m}$ polycarbonate filters, were counted under UV excitation using an epifluorescence microscope (Porter \& Feig 1980). To assess the contribution of haloarchaea to the prokaryotic community, samples were treated with $0.025 \%$ sodium taurocholate (Sigma Chemical; Oren 1990). Sodium taurocholate is a bile salt known to lyse haloarchaea. Thus, haloarchaeal abundance can be estimated from the difference in counts between untreated samples (i.e. PA) and samples treated with $0.025 \%$ sodium taurocholate. PHP was measured by the [ ${ }^{3} \mathrm{H}$-methyl] thymidine $\left({ }^{3} \mathrm{H}-\mathrm{TdR}\right)$ incorporation method (Ducklow et al. 1992). Then, 1 to $5 \mathrm{ml}$ of triplicate samples was incubated in sterile polypropylene tubes. Final concentrations of $\mathrm{TdR}$ (Amersham, $82 \mathrm{Ci} \mathrm{mmol}^{-1}$ ) were 50 to $250 \mathrm{nM}$ for inlet seawater and low-salinity $(<100 \%$ o) samples and $250 \mathrm{nM}$ for samples with salinities $>100 \%$. These additions of TdR were also employed in the substrate-addition and temperature-treatment experiments (see below). All the tubes were incubated in the dark for ca. $30 \mathrm{~min}$ at in situ water temperature. Two formaldehyde-killed samples (final conc. $2 \%$ ) served as blanks. After incubation, TdR incorporation was stopped by adding $2 \%$ formaldehyde (final conc.). The samples were kept on ice, filtered onto $0.22 \mu \mathrm{m}$ cellu- 
lose nitrate filters (Whatman) and rinsed 3 times with $5 \mathrm{ml}$ of $5 \%$ ice-cold TCA (trichloracetic acid) and subsequently 3 times with $5 \mathrm{ml}$ of $80 \%$ ice-cold ethanol. The filters were placed into scintillation vials and dissolved in $1 \mathrm{ml}$ of ethyl acetate. Then, $10 \mathrm{ml}$ of liquid scintillation cocktail (Lumagel) was added, and the samples were counted in a scintillation counter. The incorporated radioactivity was converted to cells produced using a theoretical conversion factor of $1.0 \times 10^{18}$ cells $\mathrm{mol}^{-1}$ TdR incorporated (Findlay et al. 1991).

Isotope dilution experiments were run to evaluate the effective pool of TdR in 3 saltern samples $(102,159$ and $390 \%$ ) in June 1999 and August 1999 (97, 260 and $315 \%$ ) and in 2 saltern samples (68 and $213 \%$ ) in October 1999. The samples were incubated with ${ }^{3} \mathrm{H}-\mathrm{TdR}$ (final conc. of $50 \mathrm{nM}$ ) and diluted with increasing amounts of unlabeled $\operatorname{TdR}(0,25,50,100$ and $200 \mathrm{nM})$. The effective pool of TdR was undetectable for samples with salinities $<100 \%$, but ranged from undetectable to $190 \mathrm{nM}$ for salinities between 100 and $260 \%$, and between 165 to $190 \mathrm{nM}$ for crystallizer samples (data not shown), indicating that addition of $250 \mathrm{nM}$ of $\mathrm{TdR}$ might only result in a little isotope. To assess the factors regulating PHP, $50 \mu \mathrm{M}$ (final conc.) supplements of either glucose, amino acids (mixture of L-alanine, L-asparagine and L-glutamate in 2001), or glycine betaine were added to samples from 2 to 3 salt ponds and the inlet in June, August and October 1999 and April, June and August 2001. The treated samples were incubated at in situ temperature in the dark, and ${ }^{3} \mathrm{H}$-TdR incorporation rates were measured as described above. The influence of temperature on PHP was determined at both $5^{\circ} \mathrm{C}$ higher and lower than in situ temperature using samples from August and October 1999, and ${ }^{3} \mathrm{H}$-TdR incorporation rates were measured.

Ectoenzyme activities. Ectoenzyme activities were measured using 4-methyl-umbelliferyl- $\beta$-D-glucopyranoside (MUF- $\beta$ Glc; final conc. of $300 \mu \mathrm{M}$ ) and L-leucine 7-amido-4-methylcoumarin (Leu-AMC; final conc. of $350 \mu \mathrm{M}$ ) according to the method of Hoppe (1983) and Martinez \& Azam (1993). The fluorescently tagged substrates, dissolved in methylcellosolve, were added at saturating concentrations as determined by substratesaturation experiments (medians of half-saturation constants $\left[K_{\mathrm{m}}\right]$ were $145 \mu \mathrm{M}$ for aminopeptidase and $76 \mu \mathrm{M}$ for $\beta$-glucosidase). Thus, the measured rates of ectoenzyme activities represent the maximal velocity of hydrolysis. Of the substrates, $200 \mu \mathrm{l}$ was added to $10 \mathrm{ml}$ saltern samples and incubated in the dark at in situ water temperature for $20 \mathrm{~min}$ to $1 \mathrm{~h}$. At the beginning $\left(T_{0}\right)$ and the end $\left(T_{1}\right)$ of the incubation, a fraction of water $(2.5 \mathrm{ml})$ was taken; it was transferred into a $1 \mathrm{~cm}$ quartz cuvette, and $0.2 \mathrm{ml}$ Borax buffer ( $\mathrm{pH} 10.0$ ) was added. Fluorescence intensity was read at $460 \mathrm{~nm}$ with an excitation wavelength of $365 \mathrm{~nm}$ using a fluorometer (Hoefer TKO 100, Hoefer
Phamacia). Calibration curves were obtained using varying concentrations of MUF and AMC. The difference in fluorescence units between $T_{0}$ and $T_{1}$ was expressed in terms of hydrolysis velocity $\left(\mathrm{nM} \mathrm{h}^{-1}\right)$ using calibration curves. All assays were done in triplicate.

Other analyses. Water temperature was measured using a digital thermometer (APPA 51, APPA Technology). Salinity in the solar saltern was measured by diluting saltern waters with distilled water to fall within the scale of a Temperature/Conductivity/Salinity Instrument (YSI 30, YSI, OH) or refractometer. Dissolved mono( $\mathrm{MCHO}$ ) and total saccharide (TCHO) concentrations were measured by the method of Myklestad et al. (1997). Polysaccharide (PCHO) concentrations were calculated by subtracting the MCHO concentration from the TCHO concentration after hydrolysis. Some samples with high carbohydrate concentrations were diluted with distilled water before analysis. Analysis of variance (ANOVA), $t$-tests, simple regressions and multiple regressions were performed using SPSS for Windows (Version 8.0, SPSS).

\section{RESULTS}

\section{Temperature and carbohydrate concentrations}

Salt pond temperatures increased along the salinity gradient. Temperatures in the crystallizer were 2.3 to $14.0^{\circ} \mathrm{C}$ higher than those in the seawater inlet (Fig. 1A). In October 1999 and September 2001, temperatures in some saltern ponds were slightly lower than the temperatures observed in the seawater inlet in summer. TCHO concentration was highest $\left(19.7 \mathrm{mmol} \mathrm{Cl}^{-1}\right)$ at the crystallizer in August 2001. In June 1999, carbohydrate concentrations in the crystallizer were not measured. PCHO represented the major fraction (mean $\pm \mathrm{SD}$ : $79.2 \pm$ $18.2 \%, \mathrm{n}=38$ ) of $\mathrm{TCHO}$ in the solar saltern throughout the study. In June and August 2001, however, PCHO comprised only $47 \%$ of the TCHO concentration in the crystallizer and 29 to $39 \%$ in saltern ponds of 100 to $260 \%$ (Fig. 1C). The highest PCHO concentrations of $\sim 7$ and $19 \mathrm{mmol} \mathrm{Cl}^{-1}$ were observed in ponds of 58 to $170 \%$ in June 2001 and in ponds of 290 to $310 \%$ in August 2001, respectively (Fig. 1C).

\section{Prokaryotic abundance}

PA generally increased with salinity by 8 - to 40 -fold, and PA values $>0.5 \times 10^{11}$ cells $\mathrm{l}^{-1}$ were usually found at salinities $>300 \%$ (Fig. 1D). In summer, taurocholatesensitive prokaryotes (i.e. haloarchaea, ca. $50 \%$ of total PA) were observed in salt ponds of $>272 \%$ (Fig. 1D). Haloarchaeal abundance was very low $(<1 \%$ of total PA) in low-salinity ponds. 
1999
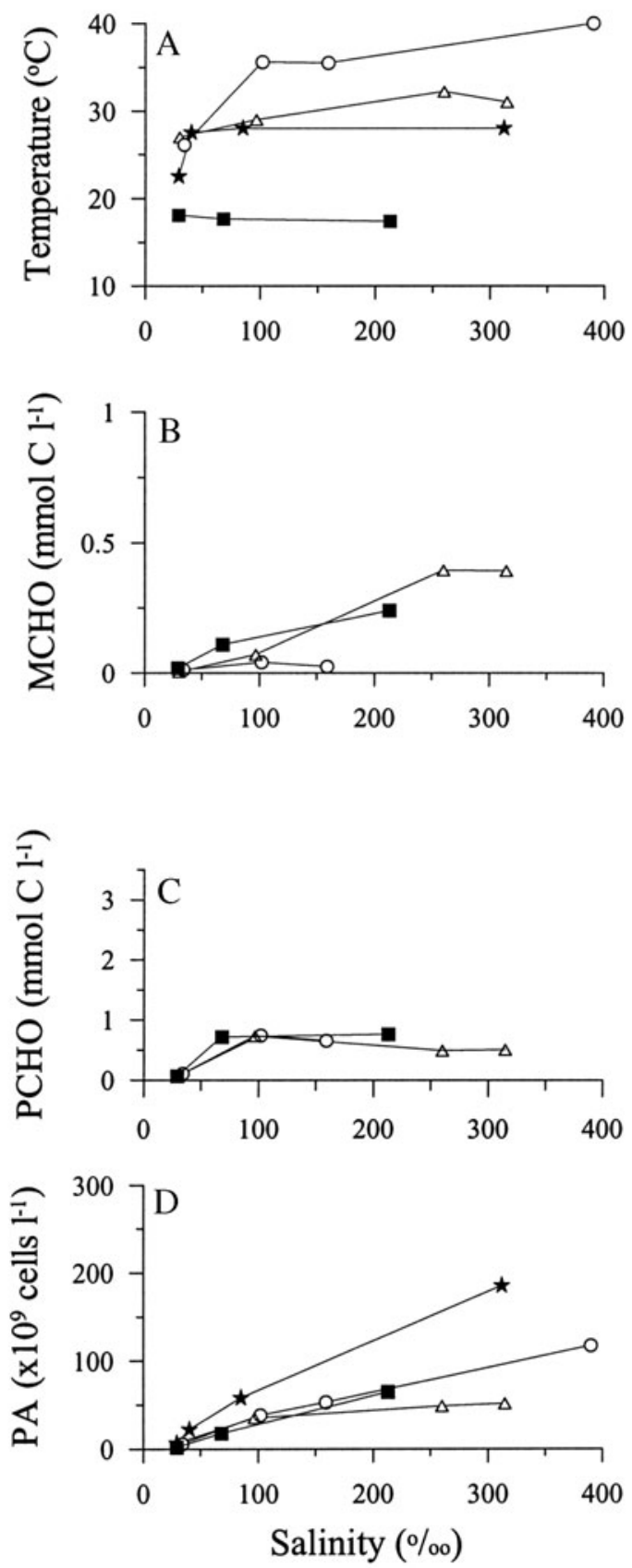

2001
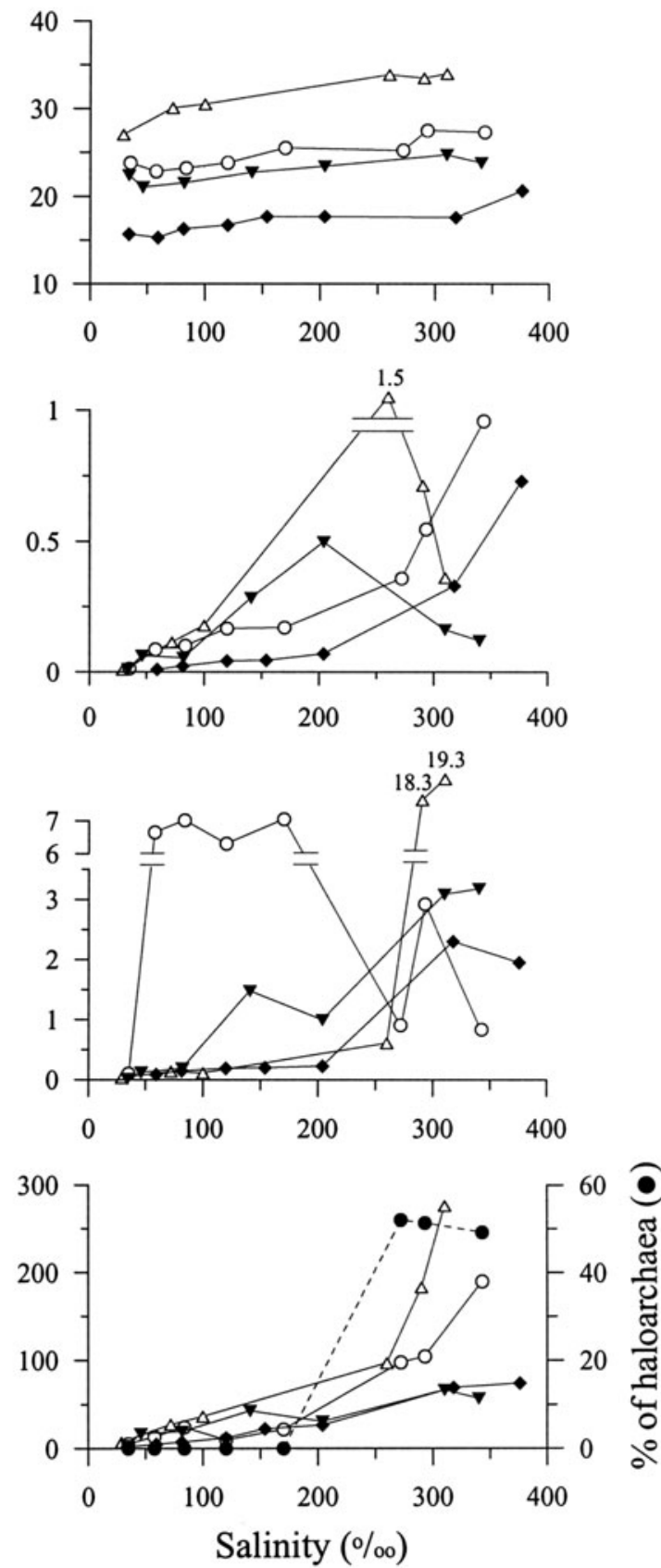

Fig. 1. (A) Temperature, (B) monosaccharides (MCHO), (C) polysaccharides (PCHO) and (D) prokaryotic abundance (PA) in ponds of varying salinity during 2 seasonal cycles in 1999 and 2001. Left-hand panels: October $1998(\star)$, June (O), August $(\Delta)$, October $(\boldsymbol{\square})$ 1999; right-hand panels: April $(\bullet)$, June $(O)$, August $(\Delta)$, September $(\boldsymbol{\nabla})$ 2001. $\mathbf{0}$ : percentage of halobacteria estimated in June 2001 by taurocholate treatment

\section{Prokaryotic heterotrophic production and ectoenzyme activities}

PHP measured by ${ }^{3} \mathrm{H}-\mathrm{TdR}$ incorporation consistently showed a peak $\left(11\right.$ to $23 \times 10^{8}$ cells $\left.\mathrm{l}^{-1} \mathrm{~h}^{-1}\right)$ in summer and autumn at salinities from 40 to $102 \%$, and then decreased towards the crystallizers in 1999 (Fig. 2A). In spring and autumn 2001, however, peaks of PHP were found at higher salinities of 141 to $154 \%$ (Fig. 2A). The highest PHP $\left(110 \times 10^{8}\right.$ cells $\left.\mathrm{l}^{-1} \mathrm{~h}^{-1}\right)$ was found in a salt 

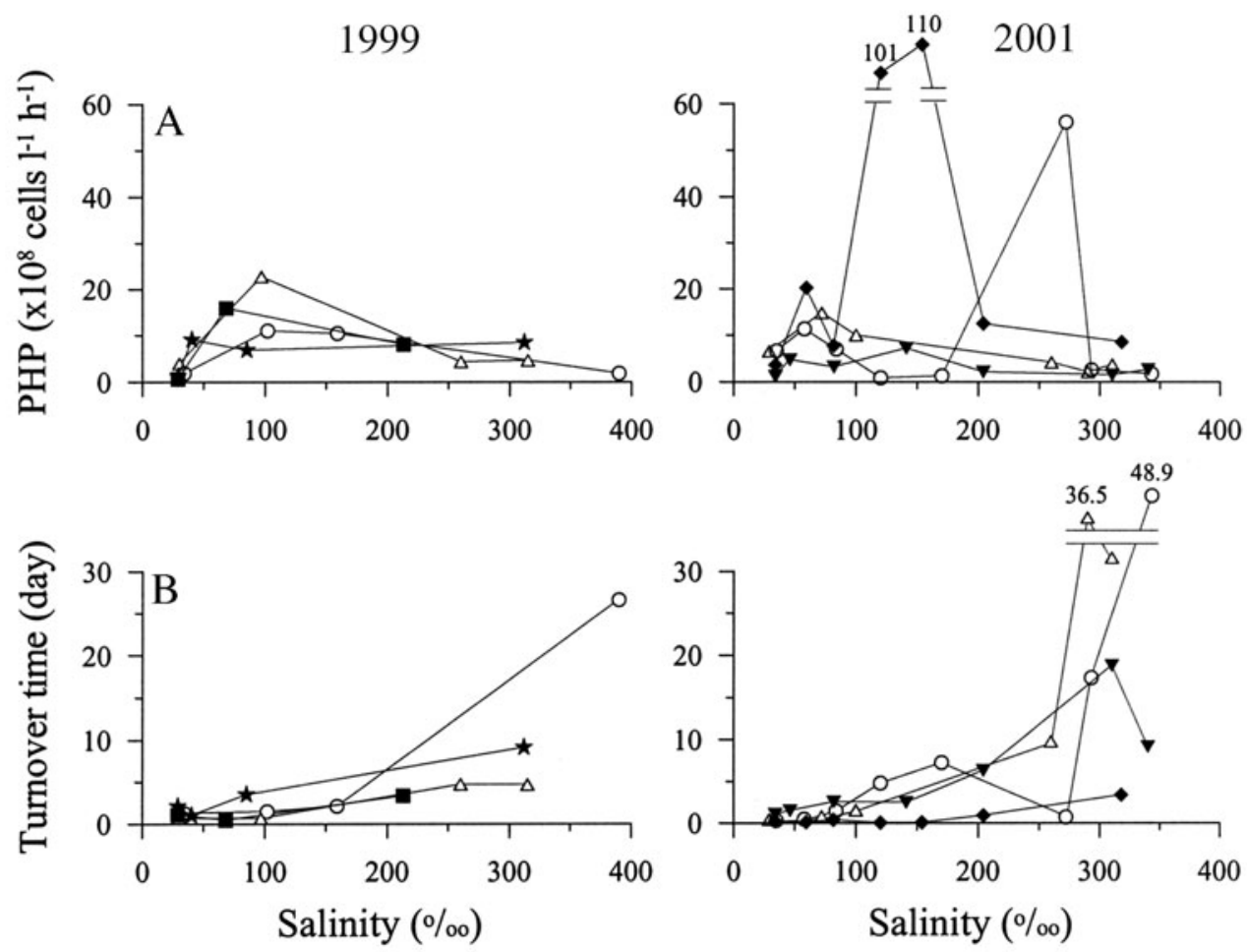

Fig. 2. (A) Prokaryotic heterotrophic production (PHP) determined by ${ }^{3} \mathrm{H}$-thymidine incorporation and (B) turnover time of prokaryote abundance in ponds of varying salinities during 2 seasonal cycles in 1999 and 2001. Symbols as in Fig. 1

pond of $154 \%$ in spring 2001. However, a major peak of PHP $\left(56 \times 10^{8}\right.$ cells l$\left.^{-1} \mathrm{~h}^{-1}\right)$ was observed in $272 \%$ in June 2001. PHP in the crystallizers was generally similar to that observed in the inlet. The PA turnover time increased with increasing salinity (Fig. 2B). The doubling time of PA was shortest (0.05 to $0.38 \mathrm{~d}$ ) in lowsalinity ponds (34 to $120 \%$ ) in the saltern in spring 2001 (Fig. 2B).

Peak aminopeptidase activity (2069 to $14561 \mathrm{nM} \mathrm{h}^{-1}$ ) was found in a salinity range of 68 to $159 \%$ o (Fig. 3A). Aminopeptidase activities in the crystallizers (13 to $537 \mathrm{nM} \mathrm{h}^{-1}$ ) were 2 to $58 \%$ of those in the inlet. Aminopeptidase activities in the saltern were much higher in 2001 than in 1999. Per-cell aminopeptidase activities in 1999 ranged from 44.3 to $130.7 \mathrm{amol} \mathrm{cell}^{-1} \mathrm{~h}^{-1}$ for low-salinity $(<120 \%$ ) waters and 0.4 to $162.2 \mathrm{amol}$ cell $^{-1} \mathrm{~h}^{-1}$ at salinities $>120 \%$ (Fig. 3A). Per-cell aminopeptidase activities in 2001 showed a similar trend to that in 1999, but with elevated values in low-salinity ponds. Peak $\beta$-glucosidase activity ( 11 to $592 \mathrm{nM} \mathrm{h}^{-1}$ ) was generally found in the salinity range from 40 to $159 \%$ (Fig. 3B). $\beta$-glucosidase activities in the saltern in summer were similar in 1999 and 2001. Per-cell $\beta$-glucosidase activities ranged widely, from 0.1 to $26.5 \mathrm{amol} \mathrm{cell}^{-1} \mathrm{~h}^{-1}$ for the low-salinity range $(<120 \%)$, dropping to 0.01 to $2.9 \mathrm{amol} \mathrm{cell}^{-1} \mathrm{~h}^{-1}$ at salinities $\geq 120 \%$ (Fig. 3B).

\section{Substrate-addition and temperature-treatment experiments}

In June and August 1999, addition of betaine significantly (ANOVA, p < 0.05) increased PHP in the crystallizer (390\%) and in the $260 \%$ salt pond (Fig. 4), suggesting the presence of osmotic stress for the prokaryotes. Although statistically insignificant, increases in PHP in the presence of betaine were also observed in the 97\% pond in August 1999. Interestingly, when an addition of betaine showed a stimulatory effect on PHP, the ratio of aminopeptidase to $\beta$-glucosidase activity was lowest (i.e. 1) (Figs. 3C \& 4). In April 2001, when PHP was very high at $120 \%$ salinity, addition of either the amino acid mixture or glucose caused a significant increase in PHP. Varying temperature in August 1999 did not seem to affect PHP in the 3 ponds $(30,260$ and $315 \%$ ) examined (data not shown), indicating a broad temperature optimum. Temperature treatments in $97 \%$ salinity ponds in August 1999 significantly reduced PHP, indicating that in situ temperature was optimal for prokaryotes. In October 1999, increased temperature stimulated PHP in 3 salt ponds $(29,68$ and $213 \%)$, indicating that PHP was temperature limited in the saltern in autumn. 

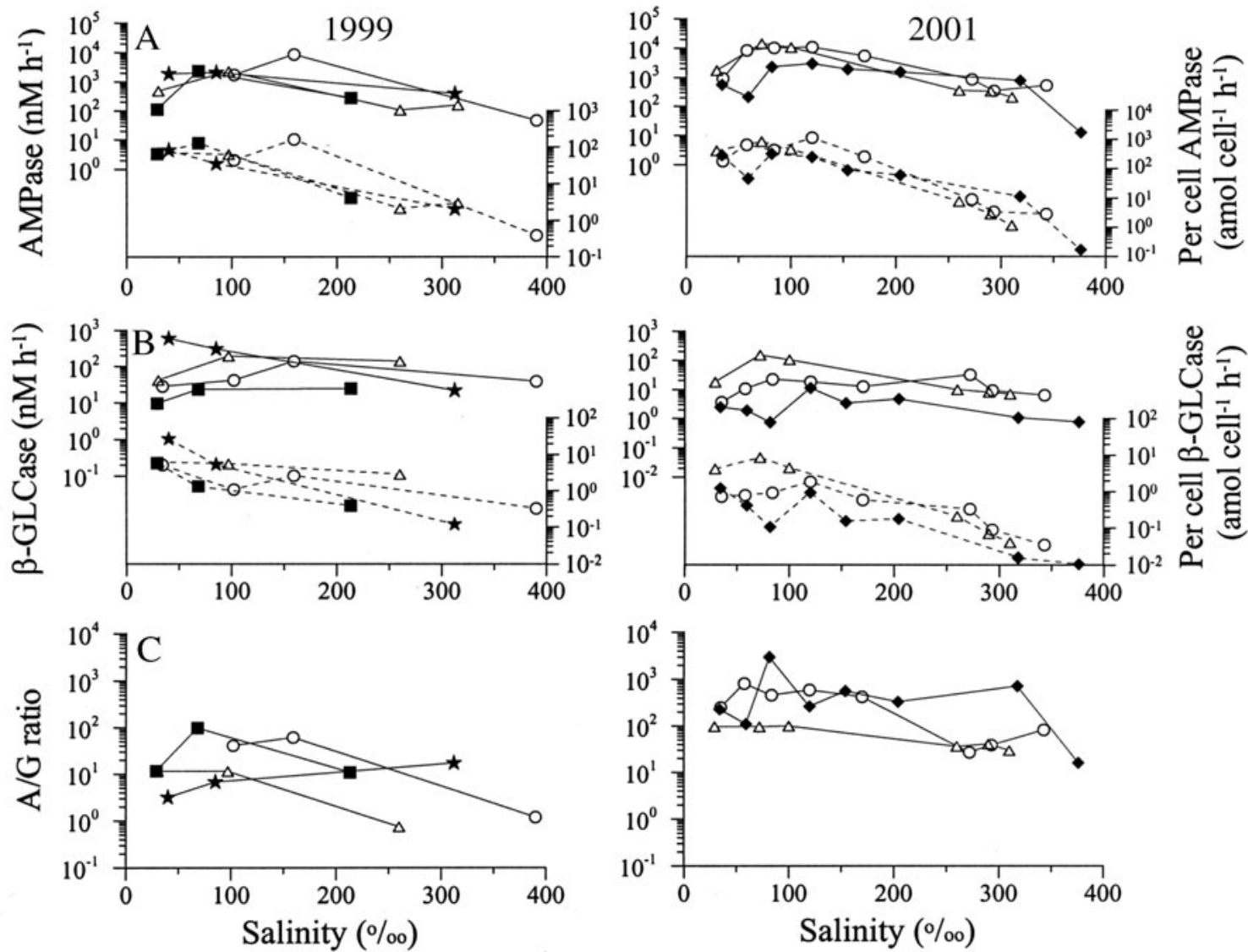

Fig. 3. (A) Aminopeptidase activity (AMPase, solid lines) and per-cell AMPase activity (dashed lines), (B) $\beta$-glucosidase activity ( $\beta$-GLCase, solid lines) and per-cell $\beta$-GLCase activity (dashed lines) and (C) ratio of AMPase to $\beta$-GLCase activity (A/G ratio) in ponds of varying salinities during 2 seasonal cycles in 1999 and 2001. Symbols as in Fig. 1

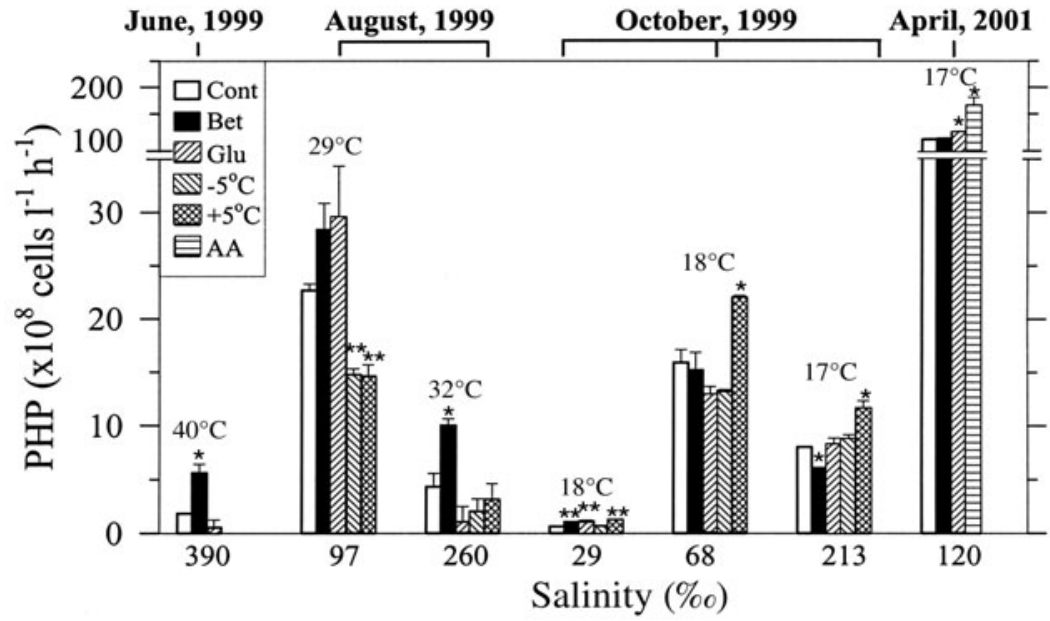

Fig. 4. Summary of the substrate-addition (Cont: control; Bet: betaine; Glu: glucose; AA: amino acids) and temperature-treatment $\left(+5^{\circ} \mathrm{C}\right.$ : in situ $+5^{\circ} \mathrm{C}$; $-5^{\circ} \mathrm{C}$ : in situ $-5^{\circ} \mathrm{C}$ ) experiments done in a Korean saltern. Asterisks denote a significant effect on prokaryotic heterotrophic production (PHP), determined by ${ }^{3} \mathrm{H}$-thymidine incorporation $\left({ }^{*} \mathrm{p}<0.05,{ }^{* *} \mathrm{p}<0.01\right)$. Temperature-treatment experiments were done in August and October 1999; substrate-addition experiments were done in June, August and October 1999 and in April, June and September 2001. In situ temperatures are shown at the top of the bars

\section{DISCUSSION}

Both culture-dependent and -independent methods have shown that marine bacteria predominate in salt-enriched and saltern samples with salinities up to $120 \%$ (Ventosa et al. 1984, Casamayor et al. 2002). Thus, in $<120 \%$ o salt ponds we might expect to find some relationships between prokaryotic variables, as reported for ordinary marine environments. In fact, in low-salinity $(<120 \%$ o) ponds, $\beta$-glucosidase activity showed significantly positive correlations with PA $\left(\mathrm{r}^{2}=0.57, \mathrm{p}<0.01, \mathrm{n}=17\right.$; Table 1) and temperature $\left(\mathrm{r}^{2}=0.56, \mathrm{p}<\right.$ 0.01, n = 17; Fig. 5A). Aminopeptidase activity was positively correlated with PA $\left(\mathrm{r}^{2}=0.51, \mathrm{p}<0.01, \mathrm{n}=16\right.$; Table 1$)$ and to some extent with temperature ( $p=0.07$; data not shown). In addition, aminopeptidase activity was positively 
Table 1. Significant relationships found between variables in low- $(<120 \%)$ and high-salinity $(\geq 120 \%$ o ponds in summer and nonsummer (spring/autumn) periods and tests of relationships for seasonal difference. PA: prokaryotic abundance; PHP: prokaryotic heterotrophic production; GLCase: $\beta$-glucosidase activity; AMPase: aminopeptidase activity; per-cell AMPase: per-cell aminopeptidase activity; per-cell GLCase: per-cell $\beta$-glucosidase activity; PTT: prokaryotic turnover time; PCHO: polysaccharide concentration ${ }_{i}{ }^{\mp}$ : negative correlation; ns: not significant; ${ }^{*} \mathrm{p}<0.05 ;{ }^{* *} \mathrm{p}<0.01$

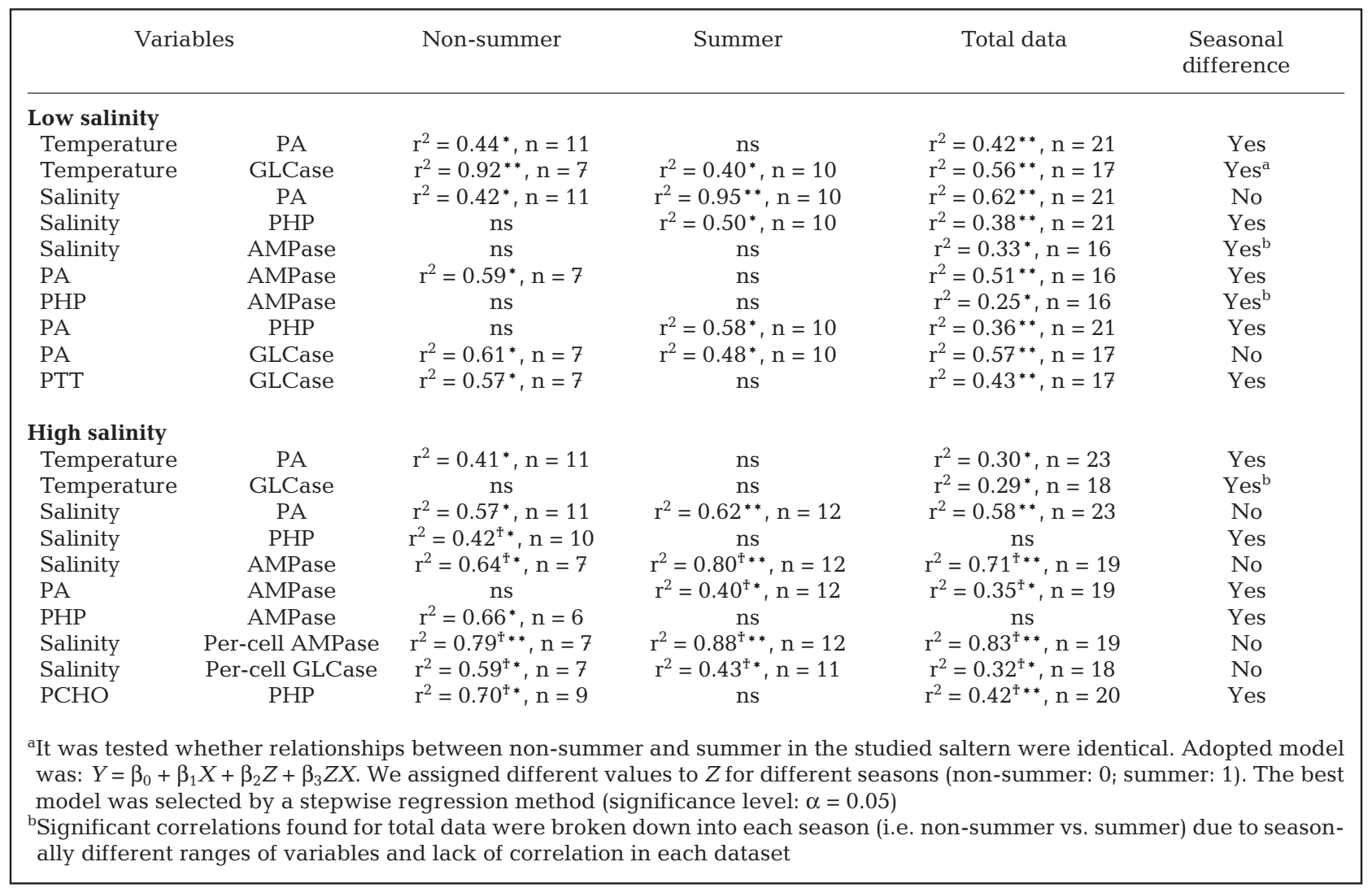

correlated with PHP in low-salinity ponds $\left(\mathrm{r}^{2}=0.25, \mathrm{p}<\right.$ 0.05, $\mathrm{n}=16$; Fig. 5B), whereas the correlation between $\beta$-glucosidase activity and PHP was insignificant $(\mathrm{p}=$ 0.39; data not shown), indicating that PHP in the saltern was more dependent on peptides in $<120 \%$ salt ponds. Overall, the above results are consistent with the reports that ectoenzyme activities are closely coupled with temperature, PA, or PHP in ordinary marine environments (Hollibaugh \& Azam 1983, Martinez \& Azam 1993, Rath et al. 1993, Christian \& Karl 1995). In highsalinity $(\geq 120 \%$ ) ponds, the ectoenzyme correlations observed in low-salinity ponds became either insignificant or weak (Table 1). For instance, $\beta$-glucosidase activity did not significantly correlate with PA, but weakly correlated with temperature $\left(\mathrm{r}^{2}=0.29, \mathrm{p}<0.05, \mathrm{n}=18\right.$; Fig. 5A). Further, the relationship between aminopeptidase activity and PHP became insignificant in $\geq 120 \%$ salt ponds ( $p>0.3$; data not shown). Thus, the only significant relationships for ectoenzyme activities in $\geq 120 \%$ salt ponds were aminopeptidase activity versus salinity and aminopeptidase activity versus PA. Interestingly, aminopeptidase activity showed a strongly negative correlation with salinity in high-salinity ponds $\left(\mathrm{r}^{2}=0.71, \mathrm{p}<0.01, \mathrm{n}=19\right.$; Table 1, Fig. $\left.5 \mathrm{C}\right)$, but a weakly positive one in low-salinity ponds $\left(\mathrm{r}^{2}=0.33, \mathrm{p}<\right.$ 0.05, $\mathrm{n}=19$; Table 1, Fig. 5C). Overall, high salinity seems to retard aminopeptidase activity in $\geq 120 \%$ salt ponds. The notion of reduced ectoenzyme activities in high-salinity ponds is further supported by 2- to 3order-of-magnitude decreases in per-cell ectoenzyme activities from $120 \%$ salinity to crystallizers (Fig. 3A,B) and by negative correlations of per-cell ectoenzyme activities with salinity (per-cell aminopeptidase: $\mathrm{r}^{2}=0.83$, $\mathrm{p}<0.01, \mathrm{n}=19$; per-cell $\beta$-glucosidase: $\mathrm{r}^{2}=0.32, \mathrm{p}<$ $0.05, \mathrm{n}=18$ ) in high-salinity ponds (Fig. 5C,D). Specifically, the reduced $\beta$-glucosidase activity in high-salinity ponds, despite high PA and PCHO concentrations, could be explained by end-product inhibition, allowing accumulation of the catalytic substrate (Chróst 1990). $\mathrm{MCHO}$ concentrations were up to 2 orders of magnitude higher in high-salinity ponds than in low-salinity ponds (Fig. 1B). However, an inverse relation between $\mathrm{MCHO}$ and $\beta$-glucosidase activity as a result of the end-product regulation of $\beta$-glucosidase was not ob- 

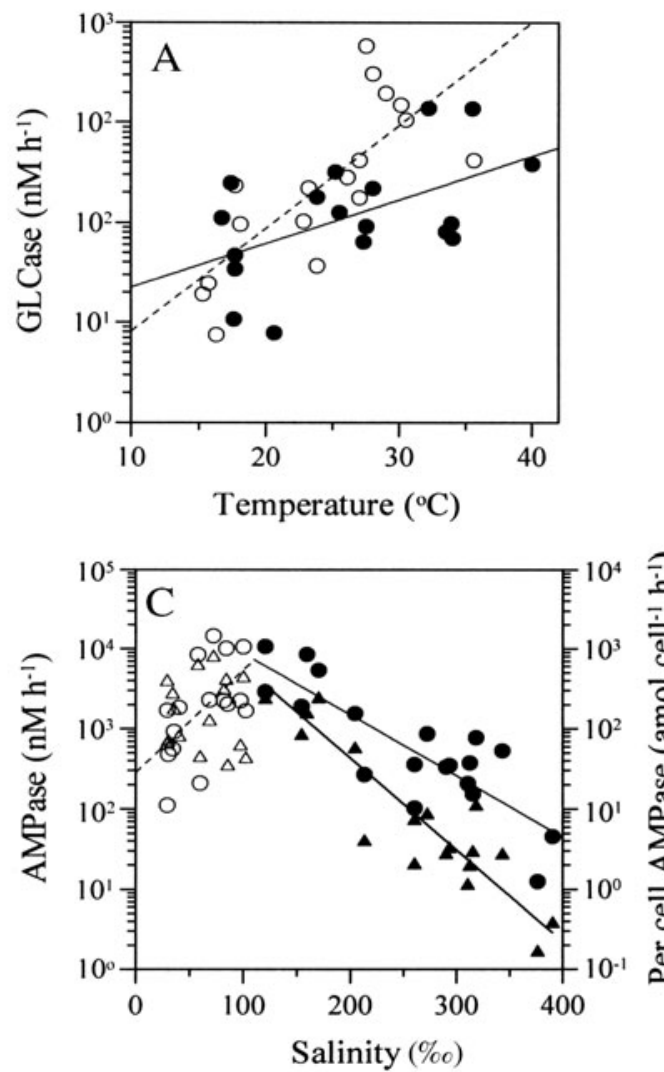
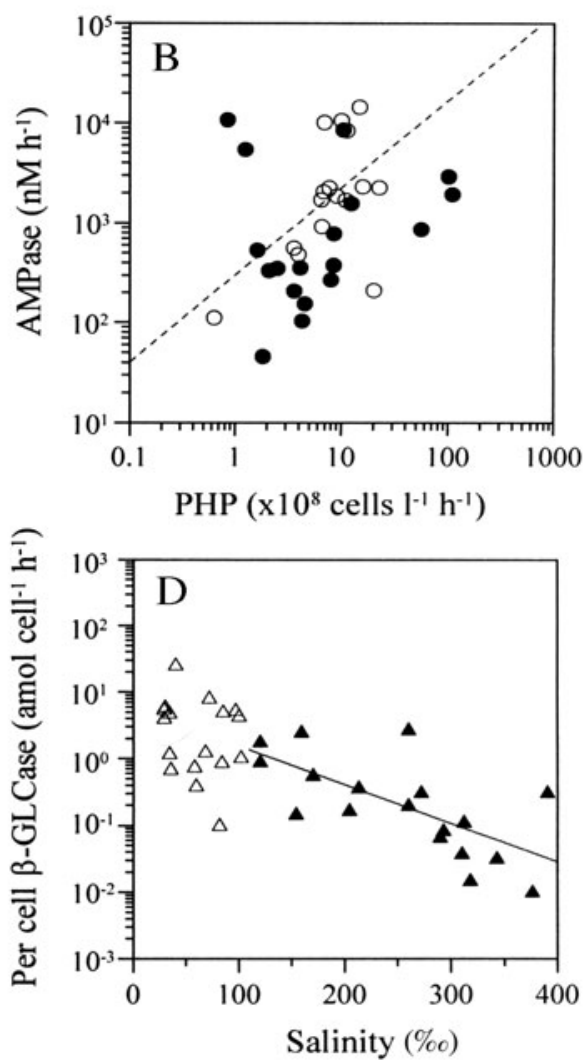

Fig. 5. Relationships of (A) $\beta$-glucosidase activity (GLCase) with temperature, (B) aminopeptidase activity (AMPase) with prokaryotic heterotrophic production (PHP), (C) AMPase $(\mathrm{O}, \mathbf{0})$ or per-cell AMPase $(\Delta, \mathbf{\Delta})$ with salinity and (D) per-cell GLCase with salinity in the studied saltern. (A-C) O, $\Delta$ : low salinity $(<120 \%)$,, $\mathbf{\Delta}$ : high salinity $(\geq 120 \%)$; dashed lines represent the regression lines for data from $<120 \%$ o ponds in the saltern. (A-D) Solid lines show data from $\geq 120 \%$ ponds. For significant relationships found between variables, see Table 1

served at salinities $>120 \%$, indicating that end-product inhibition could not be considered a major cause for the reduction of $\beta$-glucosidase activity in high-salinity ponds. Furthermore, the sharp decrease in per-cell ectoenzyme activities at salinities $\geq 260 \%$ could be partly due to changes in prokaryotic community structure, as illustrated by increases in taurocholatesensitive cells in high-salinity ponds (Fig. 1D). A similar case of succession of bacterial community during spring bloom was seen by Arrieta \& Herndl (2002).

Since high salinity has such a dominant effect on prokaryotic variables in high-salinity ponds, it might be assumed that there would be less significant seasonal effects on controlling relationships between ectoenzyme activities and prokaryotic or environmental variables. Out of 7 relationships detected both in low- and highsalinity ponds (Table 1), only 1 set of variables (i.e. aminopeptidase activity vs. salinity) in high-salinity ponds did not show a seasonally varying relationship. Two sets of variables (i.e. PA vs. PHP and prokaryotic turnover time vs. $\beta$-glucosidase activity) showed seasonally varying relationships only in low-salinity ponds. One set of variables (i.e. PCHO vs. PHP) in high-salinity ponds changed seasonally. Thus, we conclude that seasonal variations of controlling relationships between ectoenzyme activities and prokaryotic or environmental variables occurred in both high- and low-salinity ponds. Further, differing responses of PHP to varying temperatures $\left( \pm 5^{\circ} \mathrm{C}\right)$ were observed in samples in summer and autumn in the studied saltern ponds. In autumn, prokaryotes in the 68 to $213 \%$ salinity ponds were temperature limited, similar to those in coastal waters (Shiah \& Ducklow 1994), whereas prokaryotes in the saltern in summer were apparently adapted to the high in situ temperature (Fig. 4). In saltern samples from Eilat (salinity and temperature of 97 to $329 \mathrm{~g}$ dissolved salts $\mathrm{l}^{-1}$ and ca. 25 to $26^{\circ} \mathrm{C}$, respectively, in July), Oren (1990) found increased PHP following incubation at elevated temperature. The PHP of saltern samples from Eilat at $26^{\circ} \mathrm{C}$ are probably temperature controlled. Further, the prokaryotic community in the higher temperature crystallizer ( 27 to $40^{\circ} \mathrm{C}$ ) in our eutrophic saltern might have a different composition than that in the oligotrophic Eilat saltern. Comparisons of the polar lipid and metabolic profiles of 2 eutrophic solar salterns located in Newark, California, USA, and in the oligotrophic saltern at Eilat, Israel, con- 


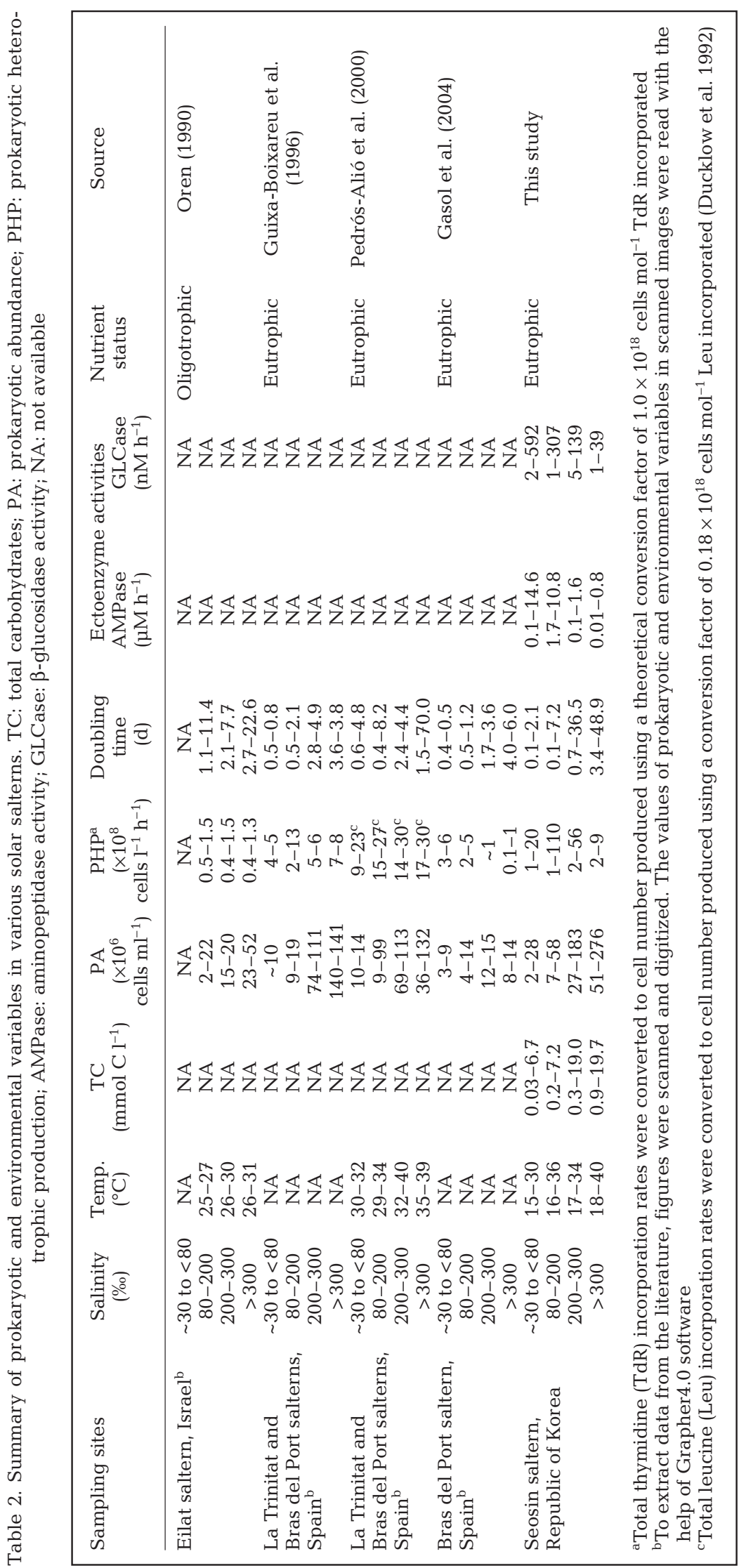

sistently showed such regional differences in the microbial communities in summer (Litchfield et al. 2000, 2001). One intriguing observation was that PHP was betaine limited only during the summer (i.e. at $260 \%$ in August and at $390 \%$ in June 1999), when the ratio of aminopeptidase to $\beta$-glucosidase activity was lowest (i.e. ca. 1). Betaine stimulation of PHP was apparent, but not significant in August 1999 at $97 \%$ salinity, when the ectoenzyme activity ratio was ca. 10. Also, in 2001, when the ectoenzyme activity ratios were always high $(>10)$, betaine stimulation of PHP was never observed. The lowest ectoenzyme ratio was due to unusually high $\beta$-glucosidase activity. The apparent association of betaine stimulation of PHP with low aminopeptidase to $\beta$-glucosidase activity ratios in the saltern might be explained as follows. In summer, prokaryotic growth was significantly controlled by $\beta$-glucosidase activity. High expression of $\beta$-glucosidase activity in actively growing, moderately halophilic bacteria under high-salinity conditions would require increases in cell volume and, subsequently, an increased demand of osmoregulatory substances. Consequently, the addition of betaine supported growth of moderately halophilic bacteria as an osmotic solute under high-salinity (>260\% in our samples) conditions (Ventosa et al. 1998). The enhanced aminopeptidase activity would cause less problem for the cells' osmoregulation compared to $\beta$-glucosidase activity, because proline (an osmoregulatory substance) or precursors of osmoregulatory substances (i.e. lysine and aspartic acid) would be transported into the cytoplasm after hydrolysis, relieving the cell from osmotic stress. Hitherto, some seasonal variations in prokaryotic growth-related variables and temperature and substrate regulation of PHP along the salinity gradient were noted, and it needs to be further confirmed whether such seasonal effects will also be found in other salterns in temperate zones.

Studies on carbohydrate concentrations in solar salterns are rather limited (Javor 1989). Our measured TCHO concentrations ( 0.1 to $19.7 \mathrm{mmol} \mathrm{C} \mathrm{l}^{-1}$ ) in the saltern are similar to those (ca. 0.1 to $16 \mathrm{mmol} \mathrm{C}$ $\mathrm{l}^{-1}$ ) reported by Javor (1989). However, no comparable data are available for PCHO in the salterns. $\mathrm{PCHO}$ is the dominant fraction 
of TCHO in oceanic surface waters (Pakulski \& Benner 1994), and PCHO also comprised a large fraction of TCHO (mean \pm SD: $79 \pm 18 \%$ ) in the saltern. PCHO concentrations measured in the inlet (13 to $108 \mu \mathrm{mol} \mathrm{C}$ $\mathrm{l}^{-1}$ ) were higher than the range of 3.3 to $24.4 \mu \mathrm{mol} \mathrm{C} \mathrm{l^{-1 }}$ reported for coastal surface samples (Børsheim et al. 1999). Possibly, this could be due to benthic algal production of $\mathrm{PCHO}$ in the shallow inlet. The high concentrations of PCHO observed in salt ponds of 100 to $250 \%$ salinity were significantly correlated with chl a $\left(\mathrm{r}^{2}=0.77, \mathrm{p}<0.01, \mathrm{n}=8\right.$; data not shown), indicating a major contribution by primary producers, as in other marine environments (Nausch \& Kerstan 2003). $\mathrm{MCHO}$ concentrations measured at the inlet seem to be within the range of 3 to $27 \mu \mathrm{mol} \mathrm{C} \mathrm{l}^{-1}$ reported for coastal surface samples (Myklestad et al. 1997, Hung et al. 2001). Interestingly, the concentration range of PCHO observed in high-salinity ponds in summer (15 to $579 \mathrm{mg} \mathrm{l}^{-1}$ ) is similar to the exopolysaccharide (EPS) yields of 35 to $370 \mathrm{mg} \mathrm{l}^{-1}$ in EPS-producing Haloarcula cultures (Nicolaus et al. 1999). Further, EPS-producing, moderately halophilic Halomonas species are known to occur in low-salinity ponds, where high PCHO concentration could be found (Béjar et al. 1998). Our observation of high PCHO supports the idea that diverse EPS-producing prokaryotes and microbes could exist in solar salterns (Quesada et al. 2004).

Environmental and prokaryote-related variables along the salinity gradient in the studied saltern showed trends generally similar to those previously observed in other salterns (Table 2). Water temperature and PA measured in the saltern gradually increased from the low- to the high-salinity ponds. The highest PA was observed in $>200 \%$ salinity ponds, and was about 1 order of magnitude higher than that in the inlet (Table 2). Likewise, PA in our saltern reached its plateau around 200 to $250 \%$, as in Spanish salterns (Pedrós-Alió et al. 2000), but often showed sharp increases at the highest salinities during the summer. In summer 2001, the PA in the crystallizers was ca. 2 to $3 \times 10^{8}$ cells ml $^{-1}$, slightly higher than the values found in La Trinitat and Bras del Port salterns by Pedrós-Alió et al. (2000) and much higher than those found in the Bras del Port saltern by Gasol et al. (2004) and the Eilat saltern by Oren (1990) (Table 2). The high PA in the studied saltern indicates the eutrophic nature of the study site. The high carbohydrate concentrations (Table 2) and chl a concentrations (highest chl a conc. of $19.2 \mu \mathrm{g} \mathrm{chl} \mathrm{a} \mathrm{l}^{-1}$ at $170 \%$; Yang 2002) also indicate that the saltern we studied is as eutrophic as Spanish salterns (Pedrós-Alió et al. 2000, Javor 2002). A large difference in PA observed between May 1999 and July $1993\left(1.6 \times 10^{7}\right.$ vs. $1.6 \times 10^{8}$ cells ml $\left.{ }^{-1}\right)$ in the Spanish saltern system was attributed to seasonal variations (Gasol et al. 2004); however, seasonal differences in PA were not always significant in our study. PHP along the salinity gradient showed notable differences among the solar salterns studied (Table 2). In solar salterns studied by Oren (1990), Guixa-Boixareu et al. (1996) and Pedrós-Alió et al. (2000), a second peak of PHP was usually observed in ponds with salinity values $>300 \%$, whereas such a peak was not observed in our study or that of Gasol et al. (2004). Generally, maximum PHP was found at salinities between ca. 80 and $250 \%$ (Table 2). Our observation that the doubling time of prokaryotes became longer than $5 \mathrm{~d}$ above $260 \%$ is consistent with the previous studies showing that prokaryotic doubling times increased above $2 \mathrm{~d}$ at salinities $>250 \%$ (Table 2). Doubling times of prokaryotes showed a similar pattern among salterns, a gradual increase from the inlet to the crystallizer (Table 2). Finally, annual variations in prokaryotic variables were detected in this study. For instance, aminopeptidase activities were much higher in 2001 than in 1999, probably due to variations in inlet seawater. Litchfield et al. (2001) also observed distinct annual variations in prokaryotic metabolic potentials in their studied salterns. Overall, the distribution patterns of prokaryoticrelated variables over seasonal and annual cycles described here show a general similarity among salterns in temperate zones, indicating that the salinity gradient strongly influences the distribution of prokaryote-related variables in the salterns.

To summarize, in a Korean solar saltern operated from spring to autumn, ectoenzyme activities seemed to be suppressed by increasing salinity. Despite the dominant influence of high salinity on prokaryotic variables, most prokaryotic variables were differently controlled over seasons in low-salinity $(<120 \%)$ and in high-salinity $(\geq 120 \%)$ ponds. In the studied solar saltern, PCHO comprised a large fraction of TCHO $(79 \%)$, similar to more typical marine environments. Furthermore, the high $\mathrm{PCHO}$ concentrations in the solar saltern suggest that solar salterns are a potential source of EPS-producing prokaryotes.

Acknowledgements. We thank Professor Russell H. Vreeland (West Chester University, USA) and Professor Gerhard J. Herndl (NIOZ, The Netherlands) for valuable corrections of the manuscript and Soosung solar saltern company for their cooperation during the study. The present study was supported (in part) by the Brain Korea 21 Project and the Korea Sea Grant Program (B.C.C.) of the Korean government.

\section{LITERATURE CITED}

Arrieta JM, Herndl GJ (2002) Changes in bacterial $\beta$-glucosidase diversity during a coastal phytoplankton bloom. Limnol Oceanogr 47:594-599

Béjar V, Llamas I, Calvo C, Quesada E (1998) Characterization of exopolysaccharides produced by 19 halophilic 
strains of the species Halomonas eurihalina. J Biotechnol 61:135-141

Billen G (1984) Heterotrophic utilization and regeneration of nitrogen. In: Hobbie JE, Williams PJL (eds) Heterotrophic activity in the sea. Plenum Press, New York, p 313-355

Børsheim KY, Myklestad SM, Sneli JA (1999) Monthly profiles of DOC, mono- and polysaccharides at two locations in the Trondheimsfjord (Norway) during two years. Mar Chem 63:255-272

Casamayor EO, Massana R, Benlloch S, Øvreås L and 6 others (2002) Changes in archaeal, prokaryotes and eukaryal assemblages along a salinity gradient by comparison of genetic fingerprinting methods in a multipond solar saltern. Environ Microbiol 4:338-348

Choi DH, Cho BC (2005) Idiomarina seosinensis sp. nov., isolated from hypersaline water of a solar saltern in Korea. Int J Syst Evol Microbiol 55:379-383

Choi DH, Yi H, Chun JS, Cho BC (2006) Jannaschia seosinensis sp. nov., isolated from hypersaline water of a solar saltern in Korea. Int J Syst Evol Microbiol 56:45-49

Christian JR, Karl DM (1995) Bacterial ectoenzymes in marine waters: activity ratios and temperature responses in three oceanographic provinces. Limnol Oceanogr 40:1042-1049

Chróst RJ (1990) Microbial ectoenzymes in aquatic environments. In: Overbeck J, Chróst RJ (eds) Aquatic microbial ecology: biochemical and molecular approaches. Springer-Verlag, New York, p 47-78

Ducklow HW, Kirchman DL, Quinby HL (1992) Bacterioplankton cell growth and macromolecular synthesis in seawater cultures during the North Atlantic spring phytoplankton bloom, May, 1989. Microb Ecol 24:125-144

Findlay S, Pace ML, Lints D, Cole JJ, Caraco NF, Peierls B (1991) Weak coupling of bacterial and algal production in a heterotrophic ecosystem: the Hudson River estuary. Limnol Oceanogr 36:268-278

Gasol JM, Casamayor EO, Joint I, Garde K and 6 others (2004) Control of heterotrophic prokaryotic abundance and growth rate in hypersaline planktonic environments. Aquat Microb Ecol 34:193-206

Guixa-Boixareu N, Calderón-Paz JI, Heldal M, Bratbak G, Pedrós-Alió C (1996) Viral lysis and bacterivory as prokaryotic loss factors along a salinity gradient. Aquat Microb Ecol 11:215-227

Hollibaugh JT, Azam F (1983) Microbial degradation of dissolved proteins in seawater. Limnol Oceanogr 28: $1104-1116$

Hoppe HG (1983) Significance of exoenzymatic activities in the ecology of brackish water: measurements by means of methylumbelliferyl substrates. Mar Ecol Prog Ser 11: 299-308

Hung CC, Tang D, Warnken KW, Santschi PH (2001) Distributions of carbohydrates, including uronic acids, in estuarine waters of Galveston Bay. Mar Chem 73:305-318

Imhoff JF, Rodriguez-Valera F (1984) Betaine is the main compatible solute of halophilic eubacteria. J Bacteriol 160: $478-479$

Javor BJ (1983) Nutrients and ecology of the Western Salt and Exportadora del Sal saltern brines. In: Schreiber BC, Harner HL (eds) Proceedings of the 6th symposium on salt, Vol 1. The Salt Institute, Toronto, p 195-205

Javor BJ (1989) Hypersaline environments: microbiology and biogeochemistry. Springer-Verlag, New York, p 53-76

Javor BJ (2002) Industrial microbiology of solar salt production. J Ind Microbiol Biotechnol 28:42-47

Joint I, Henriksen P, Garde K, Riemann B (2002) Primary production, nutrient assimilation and microzooplankton grazing along a hypersaline gradient. FEMS Microbiol Ecol 39:245-257

Litchfield CD, Irby A, Kis-Papo T, Oren A (2000) Comparisons of the polar lipid and pigment profiles of two solar salterns located in Newark, California, USA, and Eilat, Israel. Extremophiles 4:259-265

Litchfield CD, Irby A, Kis-Papo T, Oren A (2001) Comparative metabolic diversity in two solar salterns. Hydrobiologia 466:73-80

Martinez J, Azam F (1993) Periplasmic aminopeptidase and alkaline phosphatase activities in a marine bacterium: implications for substrate processing in the sea. Mar Ecol Prog Ser 92:89-97

Myklestad SM, Skånøy E, Hestmann S (1997) A sensitive and rapid method for analysis of dissolved mono- and polysaccharides in seawater. Mar Chem 56:279-286

Nausch M, Kerstan E (2003) The relationship between dissolved carbohydrates and carbohydrate-degrading enzymes in the salinity gradient of the Pomeranian Bight (southern Baltic). Oceanologia 45:437-452

Nicolaus B, Lama L, Esposito E, Manca MC and 5 others (1999) Haloarcula spp. able to biosynthesize exoendopolymers. J Ind Microbiol Biotechnol 23:489-496

Oren A (1990) Thymidine incorporation in saltern ponds of the different salinities: estimation of in situ growth rates of halophilic archaeobacteria and eubacteria. Microb Ecol 19:43-51

Pakulski JD, Benner R (1994) Abundance and distribution of dissolved carbohydrates in the ocean. Limnol Oceanogr 39:930-940

Park JS, Kim HJ, Choi DH, Cho BC (2003) Active flagellates grazing on prokaryotes in high salinity waters of a solar saltern. Aquat Microb Ecol 33:173-179

Pedrós-Alió C, Calderón-Paz JI, MacLean MH, Medina G, Marrasé C, Gasol JM, Guixa-Boixareu N (2000) The microbial food web along salinity gradients. FEMS Microbiol Ecol 32:143-155

Porter KG, Feig YS (1980) The use of DAPI for identifying and counting aquatic microflora. Limnol Oceanogr 25:943-948

Quesada E, Béjar V, Del Moral A, Ferrer MR and 7 others (2004) Moderately halophilic, exopolysaccharide-producing bacteria. In: Ventosa A (ed) Halophilic microorganisms. Springer-Verlag, Heidelberg, p 297-314

Rath J, Schiller C, Herndl GJ (1993) Ectoenzymatic activity and bacterial dynamics along a trophic gradient in the Caribbean Sea. Mar Ecol Prog Ser 102:89-96

Rodriguez-Valera F (1988) Characteristics and microbial ecology of hypersaline environments. In: Rodriguez-Valera F (ed) Halophilic bacteria, Vol 1. CRC Press, Boca Raton, FL, p 3-30

Shiah Fk, Ducklow HW (1994) Temperature and substrate regulation of bacterial abundance, production and specific growth rate in Chesapeake Bay, USA. Mar Ecol Prog Ser 103:297-308

Ventosa A, Rodriguez-Valera F, Poindexter JS, Reznikoff WS (1984) Selection for moderately halophilic bacteria by gradual salinity increases. Can J Microbiol 30:1279-1282

Ventosa A, Nieto JJ, Oren A (1998) Biology of moderately halophilic aerobic bacteria. Microbiol Mol Biol Rev 62: 504-544

Welsh DT (2000) Ecological significance of compatible solute accumulation by microorganisms: from single cells to global climate. FEMS Microbiol Rev 24:263-290

Yang DJ (2002) A comparative study on the variations of phytoplankton distribution and primary productivity at the southern SaeManKeum area and the Soosung saltern. MS thesis, Seoul National University

Submitted: April 19, 2005; Accepted: April 10, 2006

Proofs received from author(s): June 14, 2006 